9 Wang Z, Hamman MA, Huang SM, Lesko LJ, Hall SD. Effect of St John's wort on the pharmacokinetics of fexofenadine. Clin Pharmacol Ther 2002;71:414-20.

10 Wang Z, Gorski JC, Hamman MA, Huang SM, Lesko LJ, Hall SD. The effects of St John's wort (Hypericum perforatum) on human cytochrome P450 activity. Clin Pharmacol Ther 2001;70:317-26.

11 Roby CA, Dryer DA, Burstein AH. St John's wort: effect on CYP2D6 activity using dextromethorphan-dextrorphan ratios. J Clin Psychopharmacol 2001;21:530-2.

12 Wenk M, Todesco L, Krahenbuhl S. Effect of St John's wort on the activities of CYP1A2, CYP3A4, CYP2D6, N-acetyltransferase 2, and xanthine oxidase in healthy males and females. Br J Clin Pharmacol 2004;57:495-9.

13 Johne A, Brockmoller J, Bauer S, Maurer A, Langheinrich M, Roots I. Pharmacokinetic interaction of digoxin with an herbal extract from S John's wort (Hypericum perforatum). Clin Pharmacol Ther 1999;66:33845 .

14 Burstein AH, Horton RL, Dunn T, Alfaro RM, Piscitelli SC, Theodore W. Lack of effect of St John's wort on carbamazepine pharmacokinetics in healthy volunteers. Clin Pharmacol Ther 2000;68:605-19.

15 Sugimoto K, Ohmori M, Tsuruoka S, Nishiki K, Kawaguchi A, Harada K, et al. Different effects of St John's wort on the pharmacokinetics of simvastatin and pravastatin. Clin Pharmacol Ther 2001;70:518-24.

16 Markowitz JS, deVane CL, Boulton DW, Carson SW, Nahas Z, Risch SC. Effect of St John's wort (Hypericum perforatum) on cytochrome P-450 2D6 and 3A4 activity in healthy volunteers. Life Sci 2000;66:PL133-9.

17 Pfrunder A, Schiesser M, Gerber S, Haschke M, Bitzer J, Drewe J. Interaction of St John's wort with low-dose oral contraceptive therapy: a randomized controlled trial. Br J Clin Pharmacol 2003;56:683-90.

18 Wang LS, Zhou G, Zhu B, Wu J, Wang JG, El-Aty Am AA, et al. St John's wort induces both cytochrome P450 3A4-catalyzed sulfoxidation and 2C19-dependent hydroxylation of omeprazole. Clin Pharmacol Ther 2004;75:191-7.
19 Morimoto T, Kotegawa T, Tsutsumi K, Ohtani Y, Imai H, Nakano S. Effect of St John's wort on the pharmacokinetics of theophylline in healthy volunteers.J Clin Pharmacol 2004:44:95-101.

20 Durr D, Stieger B, Kullak-Ublick GA, Rentsch KM, Steinert HC, Meier PJ, Fattinger K. St John's wort induces intestinal P-glycoprotein/MDR1 and intestinal and hepatic CYP3A4. Clin Pharmacol Ther 2000;68:598-604.

21 Piscitelli SC, Burstein AH, Chaitt D, Alfaro RM, Falloon J. Indinavir concentrations and St John's wort. Lancet 2000;355:547-8.

22 Jiang X, William KM, Liauw WS, Ammit AJ, Roufogalis BD, Duke CC, et al. Effect of St John's wort and ginseng on the pharmacokinetics and pharmacodynamics of warfarin in healthy subjects. Br J Clin Pharmacol 2004:57:592-9.

23 Hebert MF, Park JM, Chen YL, Akhtar S, Larson AM. Effects of St John' wort (Hypericum perforatum) on tacrolimus pharmacokinetics in healthy volunteers. J Clin Pharmacol 2004:44:89-94.

24 Markowitz JS, Donovan JL, DeVane CL, Taylor RM, Ruan Y, Wang J, et al. Effect of St John's wort on drug metabolism by induction of cytochrome P450 3A4 enzyme. JAMA 2003;290:1500-4.

25 Dresser GK, Schwarz UI, Wilkinson GR, Kim RB. Coordinate induction of both cytochrome P4503A and MDR1 by St John's wort in healthy subjects. Clin Pharmacol Ther 2003;73:41-50.

26 Hammerness P, Basch E, Ulbricht C, Barrette EP, Foppa I, Basch S, et al St John's wort: a systematic review of adverse effects and drug interactions for the consultation psychiatrist. Psychosomatics 2003;44:271-82.

27 Markowitz JS, deVane CL. The emerging recognition of herb-drug intera pharmacol Bull 2001:35:53-64.

28 Henderson L, Yue QY, Bergquist C, Gerden B, Arlett P. St John's wort (Hypericum perforatum): drug interactions and clinical outcomes. $\mathrm{Br} J$ Clin Pharmacol 2002;54:349-56.

29 Draves AH, Walker SE. Analysis of the hypericin and pseudohypericin content of commercially available St John's wort preparations. Can J Clin Pharmacol 2003;10:114-8.

\title{
When I use a word
}

\section{Balancing benefits and harms in health care}

Some drugs yield more than one benefit. For instance, $\beta$ blockers have antihypertensive, antianginal, and antiarrhythmic effects. They also have more than one adverse effect. So we can talk about their benefits and harms. It's all to do with how you count.

The Danish philologist Otto Jespersen expounded the concept of count and non-count nouns in an unpublished lecture to the Copenhagen Academy of Sciences in 1911. As he explained in The Philosophy of Grammar (1924), you can form plurals if you can collect two things alike. For example, two bananas (two of the same thing). Or two fruits, an apple and an orange (two of the same kind). But we have no plural word for a journal plus a stethoscope, except to call them two objects, and certainly no plural word for a journal plus health care.

Music, traffic, and tact cannot be counted; arm, leg, and eye can-at least in English; in Hungarian the word for any pair of body parts is singular; one eye is referred to as a half eye. Then "you" in English denotes both singular and plural ("ye" having disappeared), while the French have "tu" and "vous." "Peut-on tutoyer?" a student asked her supervisor; the reply was stony: "Si vous voulez." Some nouns have it both ways, depending on meaning. Chocolates in a box are countable - two chocolates, a few chocolates, many chocolates (but who's counting?). Chocolate in a bar is not-much chocolate, little chocolate, less chocolate. Morbidity (sickness) is not countable, but comorbidities means diseases; competency (ability) is not countable, but "competencies" means things people can do. Both plurals are relatively new uses.

Now "harm" has two meanings, injury and an injury. And the countable sense has as long a pedigree as the uncountable one. Harms are referred to in a 10th century poem, Genesis, wrongly attributed to Caedmon: "Ealle synt uncre hearmas gewrecene." Shakespeare uses the noun harm about 90 times, and 14 of those are plural. In The Taming of the Shrew, a messenger tells Christopher Sly that his doctors "thought it good you hear a play / And frame your mind to mirth and merriment, / Which bars a thousand harms and lengthens life." And Shakespeare knew his count from his non-count: "She hath more hair than wit and more faults than hairs," says the Veronese clown, Lance, about his sweetheart. However much hair she had, she doesn't sound like a great catch.

Drugs are prescribed because of their potential benefits, but in every case there are risks of harms; before prescribing, the former should be weighed against the latter. This is commonly called assessing the "benefit to risk ratio." But benefit and risk are non-comparable: one is an actual outcome, the other a chance of one. Benefits are properly balanced by harms. However, the two are incommensurate and cannot be combined into a ratio. One should therefore talk about the benefit to harm balance, which is a complex function of the seriousness of the problem to be treated, the efficacy and safety of the drug to be used, and the efficacy and safety of other available drugs.

And that is why we have called this special issue of the BMJ "Balancing benefits and harms in health care." Jeff Aronson clinical pharmacologist, Oxford

We welcome articles up to 600 words on topics such as A memorable patient, A paper that changed my practice, My most unfortunate mistake, or any other piece conveying instruction, pathos, or humour. Please submit the article on http://submit.bmj.com Permission is needed from the patient or a relative if an identifiable patient is referred to. We also welcome contributions for "Endpieces," consisting of quotations of up to 80 words (but most are considerably shorter) from any source, ancient or modern, which have appealed to the reader. 